\title{
MAIN DIRECTIONS OF DEVELOPMENT OF SPRING WHEAT PRODUCTION AGRICULTURAL TECHNOLOGIES FOR SUSTAINABLE ARABLE FARMING IN THE FOREST-STEPPE BELT OF THE MIDDLE VOLGA REGION
}

\author{
Marat AMIROV, Kazan State Agrarian University, Address: 420015, Karl Marx st, 65, Kazan, Russia, Republic of Tatarstan \\ Igor SERZHANOV, Kazan State Agrarian University, Address: 420015, Karl Marx st, 65, Kazan, Russia, Republic of Tatarstan, \\ igor.serzhanov@mail.ru (corresponding author) \\ Farid SHAYKHUTDINOV, Kazan State Agrarian University, Address: 420015, Karl Marx st, 65, Kazan, Russia, Republic of Tatarstan, \\ ayratvaliev@mail.ru \\ Nicolay SEMUSHKIN, Kazan State Agrarian University, Address: 420015, Karl Marx st, 65, Kazan, Russia, Republic of Tatarstan,
}

\begin{abstract}
The article presents results of studies of influence of controlled and environmental factors on production process of different varieties of spring wheat carried out in different soil and climatic conditions of Middle Volga region.

The forest-steppe area of the Volga region is one of regions of Russia favorable for spring wheat growing by its natural and climatic conditions. Unbalance of nutrition elements in soil, acid soil and predominantly heavy-textured soil hamper the yield growth. Out of all factors vital for plants (light, heat, moisture and nutrition elements) under consideration, providing plants with nutrition elements and moisture are those limiting high crop yields.

he objective of our studies is increasing the crop yield with the simultaneous decrease of the produced goods cost makes it necessary to calculate in advance the possible yield level depending on the influence of different factors: environmental, crop variety and etc. The aim of our studies was to develop methods of growing high yield and high quality crops of different varieties of wheat adjusted for conditions of the forest-steppe black soil in the Volga region. Methods of research using field and laboratory tests, the method of state variety tests of agricultural cultures, phenoldisulfonic acid method, finite difference method, disperse analysis method. A set of observations, records and analysis was carried out during the experiments with implementation Russian methodological guidelines and National State Standards. Statistical processing of the yield data, economic and energy estimates was carried out by the methods recommended by Russia Scientific Research Institute of Agricultural Economy and Union Academy of Agricultural Sciences.

Having carried out the analysis of natural resources and genetic potential of the wheat varieties, systems of plant nutrition optimization and influence of their predecessors, we have obtained new data about possibility of increasing the spring durum wheat arable area. We have shown the role of different forms of using nitrogenous fertilizers (on the background of phosphorus - potassium ones) in the increase of productivity and improvement of the spring wheat grain quality. An established optimal norm for Gramma variety spring spelt corn seeding has been established for the conditions of the grey forest soil in the Fore-Kama region of the Republic of Tatarstan and the influence of their nutrition on yield has been found.
\end{abstract}

Keywords: seeding rate, predecessors, spelt corn, varieties, fertilizers, crop yield, Trans-Kama spring wheat

\section{INTRODUCTION}

High and sustainable crop yield corresponding to the quality standards is the main task of arable farming for provision food products for people, forage for live-stock animals and raw materials for industry branches. In the conditions of global challenges for agriculture and increase of risks from introduction of such modern agrotechnologies as genetic engineering, it is important to make use of positive experience of agrarian farms of Republic of Tatarstan (Nezhmetdinova, 2013).

The yield of arable crops can be increased by investing additional means in using new efficient arable technologies, high yield varieties and hybrids, agricultural machinery, fertilizers, weed killers and protection from diseases and crop pests, storage and processing of agricultural products and so on that is in the intensive way of the branch development. At the same time, the increase in demand on energy resources caused the growth of prices on agricultural machinery, fertilizers, herbicides, fuel and consequently the growth of expenses on produced products that together with the growing demand brings to constant and steady increase of food prices (Abdrashitov, 2014; Amirov, 2013; Goncharenko,2005; Zhuchenko, 2004; Serzhanov and Shaykhutdinov, 2013).

The task of increasing the crop yield with the simultaneous decrease of the produced goods cost makes it necessary to calculate in advance the possible yield level depending on the influence of environmental factors on seeds, potential crop culture, the crop variety etc. That is, it is necessary to be able to develop an exact programme of yield formation. This knowledge makes it possible to calculate and satisfy needs of plants (seeds) in controlled factors most completely, using

Copyright (C) 2017 The Authors. Published by Aleksandras Stulginskis University. This is an open-access article distributed under the terms of the Creative Commons Attribution License (CC-BY 4.0), which permits unrestricted use, distribution, and reproduction in any medium, provided the original author and source are credited. 
partially controllable and non-controllable factors to the fullest extent possible in concrete soil and climatic conditions (Nezhmetdinova, 2013; Amirov and Amirov, 2015; Ziganshin, 2001; Zhuchenko, 2004).

Technology of growing every crop culture has its own peculiarities in general, in every zone, in every farm and even in every land plot. Introduction of modern technologies of separate cultures is impossible without crop rotation farming. Crop cultures should be seeded after their best predecessors: winter crops - on complete (green-manure) fallow, spring wheat - after peas, winter crops seeded on complete (green-manure) fallow or fertilized row crops, sugar beet - after winter crops; other cultures also should be seeded after their predecessors corresponding to their biological peculiarities. Experiments carried out with fertilizers and strongly influencing agricultural methods have their biggest effect only in the case they are used in the corresponding link of crop rotation. Their aftereffect will be the greatest only when you seed cultures capable of using them up completely (Amirov and Amirov, 2015; Petrov et al., 2014).

Thus, the objective of our studies is increasing the crop yield with the simultaneous decrease of the produced goods cost makes it necessary to calculate in advance the possible yield level depending on the influence of different factors: environmental, crop variety and etc.

The aim of our studies was to develop methods of growing high yield and high quality crops of different varieties of wheat adjusted for conditions of the forest-steppe black soil in the Volga region.

\section{RESEARCH METHODS}

Methods of research using field and laboratory tests, the method of state variety tests of agricultural cultures, phenoldisulfonic acid method, finite difference method, disperse analysis method. A set of observations, records and analysis was carried out during the experiments with implementation Russian methodological guidelines and National State Standards. Statistical processing of the yield data, economic and energy estimates was carried out by the methods recommended by Russia Scientific Research Institute of Agricultural Economy and Union Academy of Agricultural Sciences.

Experiments with the spring durum wheat began on minor leached black soil in Ulyanovsk region in 1984-1987, on grey forest soil of the Fore-Kama zone in 1990-2014 and on leached soil of the Republic of Tatarstan in 2001-2003 (System of ... 2014). Various, confirmed the reliability agriculture scientific methods and State standards of the Russian Federation (GOST) have been applied (GOST 10842-89; GOST 27676-88).

Studies of the selection-genetic potential of spring wheat varieties included into the state register were carried out in the region on grey forest soil with the humus content of $2.8-4.3 \%$, with the total absorbed bases of 26.0 mg-eq. There was 103-183 labile phosphorous per $100 \mathrm{~g}$ of soil, 79-148 mg of exchangeable potassium per $1000 \mathrm{~g}$ of soil (by Kirsanov) and salt $\mathrm{pH}$ made 5.6-5.7.

Studies of the spring durum spelt corn seeds on different nutrition levels were made by using field and laboratory tests in 2012-2014. Field tests on grey forest soils of the Fore-Kama region of the Republic of Tatarstan were carried out in the fields of the subsidiary plot of the Kukmorskiy Agroservis Ltd. Company. It was the grey forest soil with heavy clayloam grain-size composition and the content of humus (by Turing) of 3.0-3.1\%,

$\mathrm{P}_{2} \mathrm{O}_{5}$ was $171-183 \mathrm{mg}$ and $\mathrm{K}_{2} \mathrm{O}$ (by Kirsanov) - 96.0-117.0 mg per $1000 \mathrm{~g}$ of soil. The total absorbed bases made $-27.0 \mathrm{mM}$, and the salt extract $\mathrm{pH}-5.1-5.3$.

The object of studies was spring wheat of Gramma variety and its predecessor was the winter rye after complete (green-manure) fallow.

The experimental design: factor A (nutrition level: 1. Without fertilizers (natural background; 2. Calculation of NPK for 2.0 tones of grain per 1 hectare; 3. Calculation of NPK for 2.5 tons of grain per 1 hectare.

Factor B (sowing norm). Four norms of sowing were tested for every nutrition level: 1-4 ml germinating seeds per hectare; $2-5 \mathrm{ml}$ seeds /hectare; 3-6 $\mathrm{ml}$ seeds/hectare; 4-7 $\mathrm{ml}$ seeds per hectare.

Nitrogenous fertilizers were used in the form of ammonium nitrate, phosphorus fertilizers in the form of double superphosphate and the potassium ones - in the form of potassium chloride.

The replication of the experiment was fourfold, placement of different nutrition level plots - randomized and the sowing norm - consecutive. The registration plot made $108 \mathrm{~m} 2$. The main soil preparation was carried out in the third decade of August. To get the planned 2 tones of spring spelt corm yield per hectare, we actually used N17 P7-10 K7-10 $\mathrm{kg} / \mathrm{hectare}$ of primary nutrient, and N28 P714-16 K22-23 kg/hectare of primary nutrient to get 2.5 tones of spring spelt corm yield per hectare.

A set of observations, records and analysis was carried out during the experiments with implementation of "The Technology of filed experiment" (Agrochemical ..., 1975; Dospekhov, 1985, Methods of..., 1972), "Technology of state tests of agricultural culture varieties" (Technique of ... 1970), and other methodological guidelines. Thus, phonological observations were carried out using the method of state variety tests of agricultural cultures; records of seedlings and plant stand before harvesting was made by calculations on three constant plots with the area of $0.55 \mathrm{~m} 2$ three times for each variant; accumulation of crude and dry biomass and leaf surface growth - by A.A. Nichiporovich (1970). The wetness and density of the topsoil and the soil hardness were defined. The number of weeds was calculated on the areas of $0.25 \mathrm{~m} 2$ in six sites of the plot in three experiments. The prevalence of diseases and crop pests on spring durum wheat and its lodging resistance were also recorded. The content of ammonium nitrate in the soil was defined by the phenoldisulfonic acid method, alkaline hydrolyzed ammonium - by Kornfield, active forms of phosphorus and potassium in drawings - by Kirsanov and Chirikov with the following definition of phosphorus on a photo-electrocalorimeter and of potassium on a flame photometer. NPK in plant samples was defined by the wet combustion method, nitrogen - by Kjeldahl, phosphorus - by colorimetric method and potassium by the flame photometer (Agrochemical... 1975; Technique of 1975). The grain 
protein was calculated by multiplying the percentage of the total nitrogen by the coefficient of 5.7; coefficients of using nitrogen, phosphorus and potassium and fertilizers from soil were defined by finite difference method of V.A. Demin (Dospekhov, 1985; Demin et al., 1970). The crop yield was registered by plots by the non-selective threshing method on the basis of $14 \%$ of moisture and $100 \%$ cleanness; the yield structure was defined by trial sheaves taken from permanent sites of each plot of land in three locations $(0.33 \mathrm{~m} 2)$. Technological characteristics of grain were defined by technologies stated in the GOST (National State Standards). Statistical processing of the yield data was made by the B.A. Dospekhov disperse analysis method (Dospekhov, 1985) economic and energy estimates was carried out by the methods recommended by Russia Scientific Research Institute of Agricultural Economy (RSRIAE) VASKhNIL (Lenin All Union Academy of Agricultural Sciences) (The list of ..., 1982; Technique of ... 1983) and scientists from Kazan State Agrarian University (Safin et al., 2010; Dmitriev and Khaliullin, 2016; Dmitriev and Khaliullin, 2016; Semushkin et al., 2014; Faizrakhmano et al., 2008; Dmitriev, 2015) correlation regression analysis was made using Statistica ver. 5.5 A software for Windows.

\section{RESEARCH RESULTS}

Professor M.F. Amirov carried out research at the department of plant growing of the Kazan State Academy of Agriculture to find how resowing and rotation with other cultures influenced the spring wheat yield (Amirov and Amirov, 2015; Amirov, 2013). When wheat was sowed after wheat, the crop yield decreased by 0.8 tons compared with sowing after peas, after barley - by 0.2 tones and after oats - by 0.58 tones (wheat and barley are seriously infected with the same kind of fungus causing root rot while oats suppresses it). Peas, winter rye and complete fallow were used as predecessors for sowing in the experiments carried out on alkaline black soil at Trans-Kama experimental station. Even though there was a high yield tendency in sowing on the complete fallow and some advantage of peas over rye, the planned yield with the grain quality corresponding to the first trade class of National State Standards 9353-90 was achieved after all predecessors with use of fertilizers (GOST 10842-89; GOST 27676-88). This means that these predecessors can really be recommended to be included into a set of technologies for growing high yields of high quality spring wheat crops in the zone. The discovered advantages of the predecessors were systematically evaluated on the large number of implemented varieties. The correct choice of varieties is one of the main conditions for successful growing of spring wheat in the regions. Varieties in demand were rather drought-, disease and crop pests resistant, well adapted to the soil and climatic conditions of the region and at the same time fertilizer responsive. This approach is explained by the desire to decrease crop production costs and by the interests of sustainable nature management taking into account ecological limitations.

The use of natural resources and adaptive characteristics of the grown varieties presuppose the in-depth assessment not only of the predecessors but also the soil and climatic conditions up to their microlevel that is for every farm, field and land plot and thorough examination of peculiarities and abilities of the varieties themselves. Only is this case will it be possible to reasonably carry out crop varieties districts depending on the situation, to select one or two appropriate varieties outs of the great number of them registered in the region even for small territories (Safin et al., 2010; Dmitriev and Khaliullin, 2016).

There is another important question of how real it is in practice to get spring wheat grain of good bread value in different agricultural climatic zones of the republic. Wheat varieties, agricultural methods, fertilizers and post-harvest grain care and other factors play a great role in this respect. The crop yield of different varieties of spring wheat sowed after winter crops, preceded by the complete fallow, was defined both by the plants productivity and their number on the unit of the area. The average productivity of one wheat head during 3-4 years of research was 0.94 gramms for the Lyuba breed, 0.96 for Priokskaya and Prokhorovka, 1.14 for Simbirka and 1.18 for Amir. The average number of productive stems just before harvesting was 411 pieces/sq m for the Lyuba, 485 for Priokskaya, 490 for Prokhorovka and 467 pieces/sq m for Amir.

Technological qualitative characteristics of the spring wheat grain vary mostly due to peculiarities of the varieties, climatic conditions and use of fertilizers. Such varieties as Simbirka, Priokskaya, Krasnoufimskaya90, Prokhorovka and Amir showed the best qualitative wheat grain characteristics. The best wheat grain quality was shown by the following breeds: the grain hardness of Simbirka was $69.1 \%$, Priokskaya - 66\%, Krasnoufimskaya - 90-70\%, Prokhorovka - 63.3\% and Amir - 72.8\%.

The use of fertilizers is the most important reserve for increasing the yield and improvement of grain quality. The norms of fertilizers are set up for the planned crop yield by the computational method taking into consideration coefficients of utilization of nutrients from soil and fertilizers. The soil acidity is also taken into account as the response of every culture depending on its biological peculiarities depends on this parameter. The low fertility fields need much nitrogen fertilizers for high yield production. In this case split fertilizing is used not to have accumulation in the soil solution of high concentration of salts that have negative impact of the field germination ability and further development of young plants, not to cause excessive tillering and infertile shooting to the disadvantage of crop yield, to prevent lodging and spreading of diseases and reduction of yields. In our experiments we actually applied N62-77 P95-105 K15-65 kg of primary nutrient per hectare in Ulyanovsk region, N70-80 P57-63 K28-30 in the Trans-Kama region of Tatarstan and N93-110 P48-68 K12-27 in the ForeKama region. Observations of the experiments showed that application of relatively small doses of fertilizers, which had in addition good balance of elements corresponding to the culture requirements, did not have any negative impact on the development of plants. The application of complete mineral fertilizer gave substantial yield growth.

The content of protein and crude gluten in the durum wheat grain increased if, together with the pre-sowing fertilizers, the wheat was additionally given nitrogen and liquid fertilizing-stimulating solutions containing microelements of $\mathrm{Cu}+\mathrm{Mo}$ in chelate form (LFSS) during the anthesis and milk line phases. Nutrition spraying was most efficient on the background of the complete mineral fertilizer on the alkaline black soil in the Trans-Kama region of Tatarstan. Maximum values of the grain unit $(770.3 \mathrm{~g} / \mathrm{l})$ were obtained on the background of fertilizers with application of nitrogen in the milk line phase. 
Economic estimates of the fertilizing schedule showed the largest efficiency on the background of fertilizers in the milk line phase. The efficiency level on the background of fertilizers in the Fore-Kama region of Tatarstan increased from 84 to 96 $\%$, in the Trans-Kama - from 103 to $112 \%$ (Amirov and Amirov, 2015; Amirov, 2013; Serzhanov and Shaykhutdinov, 2013).

In 1998-2000 professors F.S. Shaykhutdinov and I.M. Serzhanov carried out an experiment on the light grey forest soil in the Fore-Kama region of Tatarstan to find out the efficiency of application of different forms of nitrogen fertilizers combined with phosphorus-potassium ones for getting high quality and ecologically safe crop yield of spring wheat (Serzhanov and Shaykhutdinov, 2013). In average the application of nitrogen in the form of aqueous ammonia ( $\mathrm{N}-20.5 \%)$ for three years in row increased the crop yield as compared to the use of nitrogen in the form of ammonium nitrate: the yield growth on all calculated backgrounds made 0.14 tons per hectare.

The application of aqueous ammonia had nearly the same effect on the ecological characteristics of the grain quality as ammonium nitrate.

The highest energy efficiency when growing spring wheat with application of different kinds of nitrogen fertilizers was obtained in the case when the calculated crop yield was 4 tons of grain per hectare with the application of aqueous ammonia. Energy conversion efficiency made 3.52, which is by 0.25 units more that the energy efficiency with application of the ammonium nitrate.

Wheat plantings must be reliably protected from weeds, diseases and crop pests by using preventive and direct control measures, agricultural, biological and chemical direct control means. Development of plants, conditions of their growing and yield formation on the plantings should be under constant monitoring to remove arising troubles hampering the plants growth and ripening on time.

In the last years there is an increased demand not only in high quality grain for making bread (soft wheat varieties) and pastas (durum wheat varieties) but also in grain for cereal from spelt corn (chaffy wheat, two-grained wheat (amelcorn)). That was why it was necessary to carry out in-depth study of the minor two-grained wheat variety (amelcorn) in the conditions of Tatarstan.

Studies carried out by professors F.S. Shaykhutdinov and I.M. Serzhanov on the grey forest soil zone in the Fore-Kama region of Tatarstan in 2012-2014 have defined the optimum seeding rate of spring spelt corn of the Gramma variety depending on the nutrition. The studies showed that meteorological conditions had a substantial influence on the duration of the spelt corn vegetation. In the dry year of 2013, (HTI in May - August was 0.74) the vegetation period was the shortest - 72 days while in the mild 2014 (with HTI of 0.79) it made 77 days. In 2012 (HTI - 0.82) the vegetation duration was 83 days.

Table 1. The yield of spring spelt corn of the Gramma, depending on seeding rate and nutrition level, $t / h a$

\begin{tabular}{|c|c|c|c|c|c|c|c|}
\hline \multirow[b]{2}{*}{$\begin{array}{c}\text { Nutrition } \\
\text { background (A) }\end{array}$} & \multirow{2}{*}{$\begin{array}{l}\text { The seeding } \\
\text { rate, million/ha } \\
\text { (B) }\end{array}$} & \multicolumn{3}{|c|}{ Yield } & \multirow[b]{2}{*}{$\begin{array}{r}\text { Average } \\
\text { over } 3 \text { years }\end{array}$} & \multicolumn{2}{|c|}{ Increase } \\
\hline & & 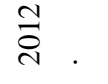 & $\stackrel{m}{\tilde{i}}$ & $\stackrel{ \pm}{\vec{i}}$ & & $\begin{array}{l}\text { At the seeding } \\
\text { rates }\end{array}$ & $\begin{array}{l}\text { The level of } \\
\text { Nutrition }\end{array}$ \\
\hline \multirow{4}{*}{ Natural background } & 4 & 1.45 & 1.49 & 1.46 & 1.47 & - & - \\
\hline & 5 & 1.50 & 1.58 & 1.53 & 1.54 & 0.07 & - \\
\hline & 6 & 1.60 & 1.69 & 1.65 & 1.65 & 0.18 & - \\
\hline & 7 & 1.55 & 1.64 & 1.77 & 1.65 & 0.18 & - \\
\hline \multirow{4}{*}{$\begin{array}{l}\text { NPK is designed for } \\
2 \text { tons of grain }\end{array}$} & 4 & 1.68 & 1.63 & 1.66 & 1.66 & - & 0.19 \\
\hline & 5 & 1.79 & 1.67 & 1.78 & 1.75 & 0.09 & 0.21 \\
\hline & 6 & 1.85 & 1.76 & 1.93 & 1.85 & 0.19 & 0.20 \\
\hline & 7 & 1.70 & 1.64 & 1.97 & 1.77 & 0.11 & 0.12 \\
\hline \multirow{4}{*}{$\begin{array}{l}\text { NPK is designed for } \\
2,5 \text { tons of grain }\end{array}$} & 4 & 1.69 & 1.70 & 1.85 & 1.75 & - & 0.28 \\
\hline & 5 & 1.80 & 1.78 & 2.02 & 1.87 & 0.12 & 0.33 \\
\hline & 6 & 1.90 & 1.85 & 2.21 & 1.99 & 0.24 & 0.34 \\
\hline & 7 & 1.73 & 1.74 & 2.17 & 1.87 & 0.13 & 0.23 \\
\hline
\end{tabular}

The number of sprouted grain increases on the natural level of nutrition (without fertilizers) from 338 to 565 seeds per $\mathrm{m} 2$ at all levels of nutrition with the increase of the seeding rate from 4 to 7 million viable seeds per hectare, and on the fertilized versions from 370 to 580 and from 376 to 580 seeds per $\mathrm{m} 2$ accordingly.

Application of calculated doses of fertilizers promoted the increase of the leaf surface value. When 6 million of viable seeds were sown per hectare, the leaf surface during the ear formation was by 5.7-9.6 thousand $\mathrm{m} 2 /$ hectare more compared to the natural background: PP - by 253-388 thousand/m2/ days/ hectare, PPP - by $1.6 \mathrm{~g} / \mathrm{m} 2$ per day. The values of the leaf surface (with the exception of the natural background), of PP and PPP increase with the increase of the seeding rate.

Fully statistically reliable crop yield in the years under study both for natural and fertilized backgrounds was achieved when sowing 6 million viable seeds per hectare. Average data for these three years show that the yield increase when sowing 6 million seeds at all nutrition levels compared to the seeding rate of 4 million made 0.18 tons per hectare on the natural background, with the calculated level of NPK per 2 tones of seeds -0.19 and per 2.5 tones of seeds -0.24 tons per hectare.

Application of calculated doses of mineral fertilizers substantially influenced the plant productivity and two-grained wheat crop yield. On average, application of fertilizers for the planned crop yield of 2 tons per hectare for all seeding rates provided additional 0.18 tons per hectare and on the background of the planned 2.5 tones/hectare -0.3 tones.

However, the maximum crop yield growth was achieved by combination of mineral nutrition with the optimum seeding rate and on the calculated background of 2 tons of grain per hectare made 0.20 tones and of 2.5 tons of grain -0.34 tons per hectare.

It was found that there is a linear dependence of crop yield from the seeding rates $(r=+0,489 \ldots 0,871$ in $2012 ; r=+$ $0,311 \ldots 0,905$ in 2013 and $\mathrm{r}=+0,569 \ldots 0,907$ in 2014). 


\section{CONCLUSIONS AND DISCUSSION}

Proceeding from the state aim of the research, all the above said and materials of field and laboratory tests make it possible to make the following conclusions. On average, application of fertilizers for the planned crop yield of 2 tons per hectare for the spelt corn for all seeding rates gave additional 0.18 tons per hectare on the background of the planned 2.5 tons/hectare -0.3 tons. The use of the seeding rate of 6 million viable seeds per hectare gave the maximum crop yield at all nutrition levels $(1.65 ; 1.85 ; 1.99 \mathrm{t} / \mathrm{ha})$. Compared with the seeding rate of 4 million seeds per hectare, these options gave the yield increase of 0.18 toned per hectare on the natural background, with the calculated level of NPK per 2 tons of seeds -0.19 and per 2.5 tons of seeds -0.24 tons per hectare.

\section{REFERENCES}

1. Abdrashitov, R.R. 2014. Influence of the main introduction of mineral fertilizers on efficiency of spring-sown field in the Orenburg Cis-Urals. PhD thesis of agricultural science.

2. Agrochemical methods of a research of soils. 1975. Science publishing house, Moscow.

3. Amirov, M. F. 2013. Influence of mineral fertilizers on productivity and quality of grain of spring-sown firm field in the conditions of the forest-steppe of the Volga region. Vestnik of Kazan State Agrarian University, No. 3(29), pp. 84-87. https://doi.org/10.12737/1354

4. Amirov, A.M., Amirov, M.F. 2015. Assessment of influence of biological medicines and mineral fertilizers on efficiency of springsown firm field. Vestnik of Kazan State Agrarian University, No. 1(35), pp. 98-102.

5. Demin, V.A., Drapkin, M.YA., Limin, B.E., Pashkov, A.B. 1979. Devices for the electrochemical analysis of natural waters by method of an inversion hronopotentsiometriya. Hydrochemical materials. Publishing House Gidrometeoizdat, Leningrad, pp. 92-98.

6. Dmitriev, A.V. 2015. New technical solution for processing of buckwheat grain / high-tech import operation in the cultivation of agricultural crops, restoration of grasslands and pastures. Training of specialists for design, creation and implementation of import operation innovative technology in agricultural production: the Scientific edition. Russian Academy of Sciences. Kazan: Publishing House of Kazan State Agrarian University, 301 p.

7. Dmitriev, A.V., Khaliullin, D.T. 2016. Pnevmo mechanical device for grain hulling. Journal of Advanced Research in Technical Science, Iss. 2, pp. 85-88.

8. Dospekhov, B.A. 1985. Methodic of field experiment (with bases of statistical processing of results of researches). 5-th ed., Publishing house Agropromizdat, Moscow.

9. Faizrakhmanov, D.I., Valiev, A.R., Nezhmetdinova, F.T., Krupina, G.D. 2008. Agrarian scientific and educational potential of the Republic of Tatarstan and the direction of its development. Vestnik of Kazan State Agrarian University, No. 3(9). pp. 5-10.

10. Goncharenko, A.A. 2005. About adaptation and ecological stability of grades of grain crops. Bulletin of Russian Academy of Agrarian Sciences, Vol. 6, pp. 25-53.

11. GOST 10842-89. Grain. Method of determination of mass of 1000 grains. 1991.

12. GOST 27676-88. Grain and products of his processing. Method of definition of number of falling. Standards Publishing House, Moscow.

13. Methods of a biochemical research of plants 1972. Under the editorship of A. I. Ermakov. Leningrad. Nezhmetdinova, F. 2013. Global challenges and globalization of bioethics. Croatian Medical Journal, Vol. 54(1), pp. 83-85. https://doi.org/10.3325/cmj.2013.54.83

14. Petrov, S.V., Shaykhutdinov, F.Sh., Serzhanov, I.M. 2014. Formation of a harvest of Diccocum spring-sown field (emmer wheat) in the conditions of the Prekama area of the Republic of Tatarstan. Grain Farm of Russia, No. 6 (36), pp. 31-38.

15. Nichiporovich, A.A. 1970. Some principles of complex optimization of photosynthetic activity and efficiency of plants of 1970 . The most important problems of photosynthesis in crop production. Kolos publishing house, Moscow, CC. pp. 120-127.

16. Zhuchenko, A.A. 2004. Resource potential of production of grain in Russia. Publishing House Agrorus, Moscow.

17. Zhuchenko, A.A. 2009. Adaptive crop production (ecology-genetic bases). Theory and Practice, Vol.2.

18. Ziganshin, A.A. 2001. Modern technologies and programming of productivity. Publishing house Kazan University, Kazan.

19. Safin, R.I., Valiev, A.R., Minyaev, R.V., Ziganshin, B.G., Nabiullin, R.Z., Nizamov, R.M. Semushkin, N.I. 2010. Formation of system of exact agriculture in the Republic of Tatarstan. Vestnik of Kazan State Agrarian University. Publishing house of the SFU, p. 165.

20. Semushkin, N. And. Yakhin S. M., Ziganshin, B., Belinskii, A. V. 2014. The study of the interaction of the seed with a rotary deflector of a seed grain drum seeders. Vestnik of Kazan State Agrarian University, No. 4(26), pp. 79-83.

21. Serzhanov, I.M., Shaykhutdinov, F.Sh. 2013. Spring-sown field in a northern part of the forest-steppe of the Volga region. CIT, Kazan.

22. System of agriculture of the Republic of Tatarstan. 2014. Agroproduction technologies of production of crop production.CIT, Kazan.

23. Shkonde, E.I. 1971. About applicability of a method of Kornfild for definition of need of soils for the Chemistry nitrogen fertilizers in agriculture. pp. 50-60.

24. Technique of test of a grade of crops, release the fourth. 1975. Kolos Publishing House, Moscow.

25. The list of indicators of properties of soils for an assessment of soil fertility and methods of their definition. 1981. Publishing House VASHNIL, Moscow.

26. Technique of a biopower assessment of the production technology of production of crop production. 1983. VASHNIL, Moscow. 